\title{
Effect of Orange and Banana Peels on the Growth Performance of Broillers
}

\author{
Farman Ali Siyal ${ }^{1}$, Rani Wagan ${ }^{*}$, Zohaib Ahmed Bhutto ${ }^{2}$, Muhammad Hamza Tareen ${ }^{1}$, \\ Muhammad Asif Arain ${ }^{2}$, Muhammad Saeed ${ }^{3}$, Sarfraz Ahmed Brohi ${ }^{2}$, Rab Nawaz Soomro ${ }^{3}$
}

\begin{abstract}
${ }^{1}$ Faculty of Veterinary and Animal Sciences, Sindh Agriculture University, Tandojam Pakistan; ${ }^{2}$ Lasbela University of Agriculture, Water and Marine Sciences, Uthal, Pakistan; ${ }^{3}$ College of Animal Sciences, Northwest A and F University, Yangling - 712100, China.
\end{abstract}

\begin{abstract}
This research was conducted for evaluation of various levels of orange and banana peels on growth performance of broilers and also predicted cost effective feed. A total of 250 day-old healthy Hubbard broiler chicks were randomly selected and divided into five groups (50 chicks / group). The group A served as control on basal diet. The groups B1 and B2 treated with orange peel (1.5 and 3.0\%), and C1/C2 treated with banana peel (1.5 and 3.0 \%) in mutually starter and grower ration throughout whole feeding trial for five weeks (35 days). Results showed that the lowest feed (3509.26) was consumed by group A and highest (3687.82 g) by group B1. Better Growth ( $2117.7 \mathrm{~g})$, live body weight ( $2161.1 \mathrm{~g})$, FCR ( 1.66), Dressing \% (63.50) and also lowest mortality (6\%) was recorded in Group C2 (3\% banana peel). The significant difference $(\mathrm{P}<0.001)$ was recorded in all growth parameters. Non-significant difference was recorded in internal body parts of broiler. The highest Rs. 41.84 per bird net profit was calculated from group C2 followed by $\mathrm{C} 1, \mathrm{~B} 2, \mathrm{~B} 1$ and $\mathrm{A}$ groups. It was concluded that addition of banana peel into the broiler ration as a feed additive up to level of $3.0 \%$ is economical and has positive effects on growth performance. However further research are required with incremental dose response to explore its effects on growth and blood biochemistry in different animal models.
\end{abstract}

Keywords | Orange peel, Banana peel, Growth performance, Economics or profit, Broilers

Editor | Kuldeep Dhama, Indian Veterinary Research Institute, Uttar Pradesh, India.

Received | June 20, 2016; Accepted | July 10, 2016; Published | July 13, 2016

*Correspondence | Rani Wagan, Faculty of Veterinary and Animal Sciences, Sindh Agriculture University, Tandojam Pakistan; Email: abrosau@yahoo.com

Citation | Siyal FA, Wagan R, Bhutto ZA, Tareen MH, Arain MA, Saeed M, Brohi SA, Soomro RN (2016). Effect of orange and banana peels on the growth performance of broilers. Adv. Anim. Vet. Sci. 4(7): 376-380.

DOI | Http://dx.doi.org/10.14737/journal.aavs/2016/4.7.376.380

ISSN (Online) | 2307-8316; ISSN (Print) | 2309-3331

Copyright (C 2016 Siyal et al. This is an open access article distributed under the Creative Commons Attribution License, which permits unrestricted use, distribution, and reproduction in any medium, provided the original work is properly cited.

\section{INTRODUCTION}

$\mathrm{F}$ or better employment of crop residues and by-products to be applied in livestock feeding needs more attention. The central crop residues and agriculture by-products of Pakistan are wheat and rice straw, citrus, tomato, mango and banana pulps and poultry litter. Poultry sector contributes significant role in the economy of Pakistan. Though, the sector of poultry sometimes is facing problems, such as shortage forages and concentrates. Meanwhile, during disposal process of agricultural wastes environment can be polluted and public health problems can be evoked. Food Agriculture Organization reported that feed price is the vital factor influencing the productivity of poultry farming, feed formulators and farmers effort to manufacture least price rations via including vegetable and fruit wastes, depending upon their rate, accessibility and nutritive worth (FAO, 2001). The agricultural wastes can be incorporated as a resource for animal feed following suitable management. However, the nutritional value of these fruit wastes is of principally important so that low cost balanced diets can be formulated for poultry especially for chicken. The previous reports indicated that fruit by-products increased the live body weight of broilers (Moghazy and Boushy, 1982; Rabayaa et al., 2001; Zafar et al., 2005; Keithly and Taggart, 2006; Oluremi et al., 2006; Oluremi et al., 2007; Soomro et al., 2013) devoid of any side effect on health status. In addition of fruit pulps, currently, peels of various fruits were sun dried and milled finally added into livestock feeding due to their nutritional values and low cost (Osei 
and Duodu, 1988; Ofuya and Obilor, 1993; Fidelibus et al., 2002; Litz, 2009). If the fruit peels are appropriately processed they could beresource of carbohydrates and minerals for livestock (Anhwange, 2008). In our environment high yield production of orange and banana fruits, but their peels were wasted. This prompted us to formulate orange and banana dried peels supplemented into diet finally fed to broilers. There were few documented reports regarding orange and banana peels (Hernan et al., 2000; Oluremi et al., 2007; Oluremi et al., 2010) in broilers and cattle. The employment of fruit peels as animal feed is indisputably a good approach of recycling this waste foodstuff. Although there is a necessity to design optimized rations for various animal uses to circumvent metabolic disorders caused by the unbalanced rations of energy and protein and to decrease the flavoursome factors which probably limit feed ingestion and then the animal performance that leads to low productivity. In our conditions, before orange and banana peels never been supplemented in the diet of broiler for growth performance. The aims of the current study were examine the growth performance of broiler chicks fed various levels of orange and banana peels and concurrently their economically analysis either profitable or not.

\section{MATERIALS AND METHODS}

\section{EXPERIMENTAL DESIGN}

The 250 day-old healthy Hubbard broiler chicks (body weight $=45.97 \pm 3 \mathrm{~g}$ ) were used in a five weeks (35 days) experiment. The broilers were randomly allotted into five groups (50 chicks/group) A, B1, B2, C1 and C2. The group A served as control on basal diet. The chicks in B1 and B2 groups fed ration with 1.5 and $3.0 \%$ levels of orange peel, and similarly same levels of banana peel supplemented in the ration of $\mathrm{C} 1$ and $\mathrm{C} 2$ groups. Then on the basis of nutritional chemical composition, the ration was formulated as depicted in Table 1 . The birds were housed in semi intensive system at Sindh Agriculture University experimental farm, Pakistan. In beginning, house was sanitized and fumigated then wooden dust spread on the floor as a litter. On day first chicks were flushed with sugar water. Both feed and water were offered ad libitum. The experimental chicks were vaccinated for major infectious diseases.

\section{Growth Performance}

The initial live body weight of chicks was measured via digital electronic balance on first day. At 35 day of age; all birds in each group were weighed using electronic top loading balance. FCR was calculated on the basis of final body and total feed intake.

\section{WATER ANd FeEd INTAKE}

The water and feed was provided two times daily (morning and evening). The water and feed refusal was collected and weighed on daily basis for calculation of final water and feed intake.
Table 1: Experimental ration (\%) included various levels of orange and banana peels

\begin{tabular}{|llllll}
\hline Ingredients & Treatments & & & \\
& A (control) & B1 & B2 & C1 & C2 \\
Rice & 25 & 25 & 20 & 25 & 20 \\
Maize & 24.5 & 23 & 29 & 23 & 29 \\
Rice polish & 5 & 5 & 4 & 5 & 4 \\
\hline Fish meal & 9 & 9 & 10 & 9 & 10 \\
\hline Soya bean meal & 7 & 7 & 8.5 & 7 & 8.5 \\
\hline Guar meal & 5 & 5 & 5 & 5 & 5 \\
\hline Canola meal & 13.5 & 14.5 & 11.5 & 14.5 & 11.5 \\
\hline Sun flower meal & 6.5 & 5.5 & 5 & 5.5 & 5 \\
\hline Rape seed meal & 3.5 & 3.5 & 3.2 & 3.5 & 3.2 \\
\hline Lime stone & 1 & 1 & 0.8 & 1 & 0.8 \\
\hline Orange Peel & - & 1.5 & 3 & - & - \\
\hline Banana Peel & - & - & - & 1.5 & 3 \\
\hline Chemical composition of ration & & & & \\
\hline Crude protein & 21.257 & 21.23 & 21.28 & 21.35 & 21.4 \\
\hline $\begin{array}{l}\text { Metabolizable } \\
\text { energy }\end{array}$ & 2851.5 & 2802 & 2801 & 2802 & 2801 \\
\hline Lysine & 1.095 & 1.099 & 1.1 & 1.099 & 1.1 \\
\hline Methionine & 0.442 & 0.44 & 0.44 & 0.44 & 0.44 \\
\hline $\begin{array}{l}\text { Cystine + } \\
\text { Methionine }\end{array}$ & 0.72 & 0.71 & 0.7 & 0.71 & 0.71 \\
\hline Calcium & 1.06 & 1.06 & 1.03 & 1.06 & 1.03 \\
\hline Phosphorus & 0.51 & 0.51 & 0.54 & 0.51 & 0.54 \\
\hline
\end{tabular}

\section{Carcass Traits}

The carcass weight was recorded on the basis of five slaughtered birds from each group at the marketing age of 35 days and dressing percentage was also calculated on the basis of dressed weight from the total live body weight of the broilers.

\section{Weight of Edible Parts}

After slaughtering birds were de-feathered and liver, heart, gizzard and intestine were removed by the help of scalpel and scissor from the birds and weighed by using electronic top loading balance.

\section{ECONOMICS}

On the basis of production of broiler after reaching the marketing age of 35 days, the per bird cost of production of each group and net returns were calculated to know the profit/loss by inclusion of orange and banana peel in the broiler feeding program.

\section{Chemical Analysis of Fruit Peels / Feed}

Before starting the actual experiment, the dried orange and banana peels were purchased from local market and 
brought to the Animal Nutrition Laboratory, Sindh Agriculture University, Pakistan for determination of Crude protein $(\mathrm{CP})$, Crude fiber $(\mathrm{CF})$ and Nitrogen free extract (NFE) by previously described method (AOAC, 2000) as mentioned in Table 2. Similarly chemical analysis of feed for Dry matter (DM), crude protein (CP), ether extracts (EE) and metabolizable energy (ME) was performed by above described method.

Table 2: Chemical Composition of dried fruit peels (\%)

\begin{tabular}{lll} 
Nutrients & Fruit peels & \\
& Orange peel & Banana peel \\
Crude protein (CP) & 7.28 & 10.84 \\
\hline Crude fiber (CF) & 10.70 & 12.94 \\
\hline Nitrogen free extract (NFE) & 61.55 & 44.85
\end{tabular}

\section{Statistical Analysis}

The data was presented as mean of five birds from each groups and analyzed by one-way ANOVA with SPSS (version 16.0) software. LSD test was used to determine whether means were significantly different $(\mathrm{P}<0.05)$.

\section{RESULTS}

\section{Feed InTAKe}

The feed consumption of A, B1, B2, C1 and C2 groups was recorded as 3509.26, 3687.82, 3660.613571 .22 and $3585.58 \mathrm{~g} / \mathrm{bird}$ respectively (Table 3 ). The lowest feed was consumed by the broilers of group A (control) and highest was consumed by group B1. Statistically, the differences in feed consumption of broiler in different groups was significant $(\mathrm{P}=0.0001)$.

\section{WATER INTAKE}

Water intake was remarkably higher 9980.29 in broilers of group C2 and lowest 9632.57 in Group A (control) whereas $9646.27,9798.22$ and $9668.38 \mathrm{ml} /$ bird was recorded in $\mathrm{B} 1, \mathrm{~B} 2$ and $\mathrm{C} 1$, respectively (Table 3). The significant difference $(\mathrm{P}=0.0001)$ was observed between the groups.

\section{Live Body Weight}

The significantly higher live body weight $(2161.10 \mathrm{~g} / \mathrm{bird})$ was observed in group $\mathrm{C} 2$ followed by broilers in groups C1 $(2106.80 \mathrm{~g} / \mathrm{bird})$. The broilers in groups B2 and B1 ranked third and fourth with average weight of 2048.4 and $2021.3 \mathrm{~g} / \mathrm{bird}$, respectively, (Table 3). The significant difference $(\mathrm{P}=0.0000)$ was seen amongst all the groups.

\section{Feed Conversion Ratio (FCR)}

Feed conversion ratio indicates the efficiency of feed to convert into weight of broiler and the results for this trait as influenced by different fruit peel levels are mention in Table 3. The broilers in group C2 resulted remarkably better FCR of 1.65 than $\mathrm{C} 1$ group (1.69). The broilers in group B2, B1 and A resulted average FCR of 1.78, 1.82 and 1.77 , respectively. The FCR values in different groups was significant $(\mathrm{P}=0.0003)$.

\section{Carcass Weight}

The mean values of carcass weight of broilers shown in Table 3. The carcass weight was maximum $(1275 \mathrm{~g} / \mathrm{bird})$ in group C2, followed by other groups C1 (1232 g/bird), B2 (1185 g/bird), B1 (1174 g/bird) and A (1089 g/bird). Statistically, the differences in carcass weight of broiler in different groups was significant $(\mathrm{P}=0.0003)$. The differences in carcass weight of broilers were highly significant $(\mathrm{P}<0.01)$ either between treatment groups or compared with control.

\section{Dressing Percentage (\%)}

Dressing percentage is directly proportional to ratio of carcass weight and the live body weight. The dressing \% was highest in group $\mathrm{C} 2(63.50 \%)$ followed by other groups $\mathrm{C} 1, \mathrm{~B} 2, \mathrm{~B} 1$ and $\mathrm{A}$, with average dressing percentage of $58.48,57.86,57.97$ and 55.03, respectively (Table 3). Statistically, significance difference in dressing percentage of broiler in groups was significant $(\mathrm{P}=0.0012)$.

\section{WEIGHT OF INTERNAL ORgans}

The mean values of important internal organs mentioned in Table 4. The liver and heart weight of broilers was affected significantly $(\mathrm{P}<0.0076,<0.0009)$ by supplementation

Table 3: Growth performance of broilers supplemented with various fruit peels at $35 \mathrm{~d}$

$\begin{array}{llllll}\text { Parameters } & \text { Groups } & & & \\ & \text { A (control) } & \text { B1 } & \text { B2 } & \text { C1 } & \text { C2 } \\ \text { Initial body weight }(\mathrm{g}) & 45.97 \pm 3 & 45.97 \pm 3 & 45.97 \pm 3 & 45.97 \pm 3 & 45.97 \pm 3 \\ \text { Feed intake }(\mathrm{g} / \mathrm{b} / \text { week) } & 3509.26^{\mathrm{c}} & 3687.82^{\mathrm{a}} & 3660.61^{\mathrm{a}} & 3571.22^{\mathrm{b}} & 3585.58^{\mathrm{b}} \\ \text { Water intake (m1/b/week) } & 9632.57^{\mathrm{b}} & 9646.27^{\mathrm{b}} & 9798.22^{\mathrm{b}} & 9668.38^{\mathrm{b}} & 9980.29^{\mathrm{a}} \\ \text { Live body weight (g/b/week) } & 1978.0^{\mathrm{d}} & 2021.3^{\mathrm{c}} & 2048.4^{\mathrm{c}} & 2106.8^{\mathrm{b}} & 2161.1^{\mathrm{a}} \\ \text { Feed conversion ratio (FCR) } & 1.77 & 1.82 & 1.79 & 1.70 & 1.66 \\ \text { Carcass weight }(\mathrm{g} / \mathrm{b}) & 1089^{\mathrm{c}} & 1174^{\mathrm{b}} & 1185^{\mathrm{b}} & 1232^{\mathrm{a}} & 1275^{\mathrm{a}} \\ \text { Dressing \% } & 58.67^{\mathrm{c}} & 60.35^{\mathrm{b}} & 61.43^{\mathrm{b}} & 62.70^{\mathrm{a}} & 63.50^{\mathrm{a}}\end{array}$

a, b, c and d: Significant difference level $(\mathrm{P}<0.05)$ 


\section{OPEN OACCESS}

of fruit peels in ration. The liver and heart weight was higher in banana peel treated groups vs orange peel treated groups. The fruits peels highly significantly increased the weight of spleen in experimental groups. The weight was noticed to be higher $(2.516$ and $2.438 \mathrm{~g} / \mathrm{bird})$ in banana peel fed groups than orange peel fed groups (2.34 and 1.86 $\mathrm{g} / \mathrm{bird})$. The gizzard weight of broilers was affected significantly $(\mathrm{P}=0.0083)$ in experimental groups. The weight of gizzard was higher in those groups fed $3.0 \%$ level of peels than groups fed $1.5 \%$ level of peels. The intestine weight was also increased significantly $(\mathrm{P}=0.0443)$ in experimental groups. The weight of organ was higher (134.8 and 132.8 $\mathrm{g} / \mathrm{bird}$ ) when broiler fed ration with 3.0 and $1.5 \%$ banana peel, and the weight was observed to be lower (131.0 and $125.0 \mathrm{~g} / \mathrm{bird}$ ) while fed 3.0 and $1.5 \%$ orange peel supplemented diet.

Table 4: Effect of various fruit peels on different organ weights of the broilers at $35 \mathrm{~d}$

\begin{tabular}{llllll} 
Group & Liver & Heart & Spleen & Gizzard & Intestine \\
\hline A (control) & 44.422 & 8.834 & 2.068 & 32.26 & 123.2 \\
B1 & 47.724 & 9.904 & 1.86 & 32.14 & 125 \\
B2 & 48.1 & 10.48 & 2.34 & 33.98 & 131 \\
C1 & 52.09 & 10.4 & 2.438 & 32.2 & 132.8 \\
C2 & 53.05 & 11.5 & 2.518 & 34.8 & 134.2 \\
P-value & $\mathbf{0 . 0 0 7 6}$ & $\mathbf{0 . 0 1 0 9}$ & $\mathbf{0 . 0 0 1 5}$ & $\mathbf{0 . 0 0 8 3}$ & $\mathbf{0 . 0 4 4 3}$ \\
\hline
\end{tabular}

\section{ECONOMICS}

The economic analysis of current trial publicized in Table 5. It clearly indicates noteworthy impact of fruit peel inclusion in the broiler ration. The total cost of each broiler production for 35 days experimental period was Rs. 211.23, 221.78, 221.78216 .74 and 217.49 in group A, B1, B2, $\mathrm{C} 1$ and $\mathrm{C} 2$, respectively. The sale price of broiler was Rs. $120 / \mathrm{kg}$ live weight, which generated a total income of Rs. 237.36, 242.55, 245.80, 252.81 and 259.33 in group A, B1, B2, C1 and C2, respectively. So the finalized net profit of Rs. 26.126, 20.773, 24.024, 36.073 and 41.84, respectively. It was observed that addition of $3.0 \%$ banana peel in broil- er ration resulted highest net profit.

\section{DISCUSSION}

The mango, apple, pine apple, citrus, banana and tomato are the major fruits used for processing in most of the Asian countries including Pakistan, and their waste can be included in livestock diets either as dry product or as silage (El Boushy and van der Poel, 2013). However, the nutritional value of these fruit wastes is of principally important so that balanced diets can be formulated for poultry especially for chicken. The present studies were carried out to determine the effect of different levels of banana and orange peels on the growth of broiler. The broiler fed ration with banana peel resulted higher live body weight and FCR as compared to broiler fed ration with orange peel. The increase in live weight of broilers fed ration with banana peel possibly due to higher protein content in contrast with broilers fed ration with orange peel. By feeding banana and orange peels from $1.5-3 \%$ will be useful and without any adverse effects on chicken body weight. But, it probably more advantageous, fed the high rates of both peels in experimental diets in broilers growing ration rather than in starter ration. Because when broilers become mature their gastrointestinal tract fully developed and works more efficiently. Hernan et al. (2000) confirmed that banana peel added into diet resulted increase in live body weight and FCR cattle. Furthermore, E1 Boushy and van der Poel (2013) reported that citrus fruits waste enhanced the FCR when compared with traditional poultry feed. Chicks receiving orange peel ration consumed less feed compared to broilers taking banana peel ration. It might be more fibre content in orange peel and may be chicks do not like the smell of feed supplemented. Moghazy and Boushay (1982) also reported that chicks growth was less who taken high fiber. The less carcass weight was noticed in boilers fed orange peel might be due to reduced feed intake, and effect of peel on abdominal fat (Oluremi et al., 2007). The more fiber intake through chick probably stimulates the bowl moments result in depression in the weight

Table 5: Economics of broilers supplemented with various fruit peels at $35 \mathrm{~d}$

\begin{tabular}{llllll} 
Particulars & GROUPS & & & & \\
& A (control) & B1 & B2 & C1 & C2 \\
Cost of day old chick (Rs/broiler) & 69.00 & 69.00 & 69.00 & 69.00 & 69.09 \\
Total cost of feed (Rs/broiler) & 91.23 & 95.88 & 95.18 & 92.84 & 93.23 \\
Cost of orange and banana peel & 0 & 5.895 & 6.598 & 3.897 & 4.256 \\
Misc. Expenditure (Rs/broiler) & 51.00 & 51.00 & 51.00 & 51.00 & 51.00 \\
Total production cost (Rs/broiler) & 211.23 & 221.78 & 221.78 & 216.74 & 217.5 \\
\hline Final live body weight (Rs/broiler) & 1.978 & 2.021 & 2.048 & 2.11 & 2.161 \\
Broiler sale rate (Rs/kg) & 120.00 & 120.00 & 120.00 & 120.0 & 120.0 \\
\hline Total income (Rs/broiler) & 237.36 & 242.55 & 245.80 & 252.81 & 259.3 \\
\hline Net profit (Rs/broiler) & 26.126 & 20.773 & 24.024 & 36.07 & 41.84 \\
\hline
\end{tabular}


OPEN ○ACCESS

gain. By supplementing orange peel in the ration although less effect on growth performance but possibly improve nutritive value and flavour of the meat. The indices of feed conversion publicized that both peels can be supplemented to broilers diets up to $1.5-3 \%$ safely devoid of side effect on feed conversion rates. Both peels increased the live body weight and growth performance of broilers, which coincide with previously reports on fruit by-products ( $\mathrm{Ra}^{-}$ bayaa et al., 2001; Zafar et al., 2005; Keithly and Taggart, 2006; Oluremi et al., 2006; Oluremi et al., 2007; Soomro et al., 2013). The increased in important organs weight was noticed possibly correlated with increased live weight and mass of the body. The highest Rs. 41.84 per bird net profit were calculated from the broilers fed $3.0 \%$ banana peel.

\section{CONCLUSION \& RECOMMENDATION}

The poultry sector in Pakistan faces obstacles of feed deficiency. It was concluded that addition of banana peel into the broiler ration as a feed additive up to level of $3.0 \%$ is the most economical and has positive effects on growth performance. However, further research are required with incremental dose response to explore its effects on growth and blood biochemistry in different animal models.

\section{ACKNOWLEDGEMENTS}

We are highly grateful to our teachers for guidance, also thankful to technicians and other staff of our laboratory for helping. We are especially thankful to Department of Poultry Husbandry for providing experimental farm.

\section{CONFLICT OF INTERESTS}

No conflict of interests are declared by authors for the contents in the manuscript.

\section{AUTHORS' CONTRIBUTION}

All authors contributed equally in all the activities to create this article.

\section{REFERENCES}

-Anhwange B (2008). Chemical composition of Musa sapientum (banana) peels. J. Food Technol. 6(6): 263-266.

-AOAC (2000). Official Methods of Analysis, Association of Official Analytical Chemists. 17th Ed. Arlington, VA.

-El Boushy A, van der Poel AF (2013). Handbook of poultry feed from waste: processing and use. $2^{\text {nd }}$ ed. Springer Sci. \& Business Media.

-FAO (2001). Private sector partnership in poultry production and marketing in India, Case study, Tamil Nadu. Proj. Report Ed. Chennai, India: Tamil Nadu Veterinary and Animal Sciences University.

-Fidelibus M, Teixeira A, Davies F (2002). Mechanical
Advances in Animal and Veterinary Sciences properties of orange peel and fruit treated pre-harvest with gibberellic acid. Trans. ASAE. 45(4): 1057. http://dx.doi. org/10.13031/2013.9920

-Hernan Botero J, Enrique Toro J, Ríos B (2000). Technicaleconomic evaluation of the use of banana peel as a supplement for cattle feed. Postcosecha y agroindustria del plátano en el Eje Cafetero de Colombia. Pp. 257-265.

- Keithly JH, Taggart T (2006). Dried citrus peel supplement for use in commercial poultry feed. Ed.: Google Patents.

- Litz RE (2009). The mango: botany, production and uses CABI. $2^{\text {nd }}$ Ed. http://dx. doi.org/10.1079/9781845934897.0000

-Moghazy MESE, Boushy AE (1982). Some neglected poultry feedstuffs from vegetable and fruit wastes. World's Poult. Sci. J. 38(01): 18-27. http://dx.doi.org/10.1079/WPS19820002

- Ofuya C, Obilor S (1993). The suitability of fermented cassava peel as a poultry feedstuff. Bioresour. Technol. 44(2): 101104. http://dx.doi.org/10.1016/0960-8524(93)90181-A

- Oluremi O, Ngi J, Andrew I (2007). Phytonutrients in citrus fruit peel meal and nutritional implication for livestock production. Livestock Res. Rural Develop. 19(7): 345-346.

-Oluremi O, Ojighen V, Ejembi E (2006). The nutritive potentials of sweet orange (Citrus sinensis) rind in broiler production. Int. J. Poult. Sci. 5(7): 613-617. http://dx.doi.org/10.3923/ ijps.2006.613.617

- Oluremi OIA, Okafor FN, Adenkola AY, Orayaga KT (2010). Effect of fermentation of sweet orange (Citrus sinensis) fruit peel on its phytonutrients and the performance of broiler starter. Int. J. Poult. Sci. 9(6): 546-549. http://dx.doi. org/10.3923/ijps.2010.546.549

- Osei S, Duodu S (1988). The use of sun dried cassava peels meal in broiler diets. J. Anim. Prod. Res. 8(2): 69-75.

-Rabayaa E, Omar JA, Othman R (2001). Utilization of olive pulp in broiler rations. An-Najah Univ. J. Res. 15: 133-144.

-Soomro H, Rind MI, Sanjrani SN, Magsi AS, Barham GS, Pirzada SH, Sahito HA (2013). Effect of partial mango pulp mixing in ration on behaviour and production of broiler. Int. J. Plant Anim. Sci. 1(1): 030-036.

- Zafar F, Idrees M, Ahmed Z (2005). Use of apple by-products in poultry rations of broiler chicks in Karachi. Pak. J. Physiol. 1: $1-2$.

July 2016 | Volume 4 | Issue 7 | Page 380 